\title{
Motivations and Factors that Contribute to Successful Drumline Groups in Malaysia
}

\author{
Helmi Rosli ${ }^{1}$ \\ ${ }^{1}$ Faculty of Music, Universiti Teknologi MARA, Malaysia \\ Correspondence: Helmi Rosli, Faculty of Music, Universiti Teknologi MARA, Level 11, Menara SAAS, UiTM \\ Main Campus, 40450 Shah Alam Selangor Darul Ehsan, Malaysia. Tel: 603-5544-2725 E-mail: \\ helmirosli@salam.uitm.edu.my \& helmibinrosli@gmail.com
}

Received: November 9, 2018

doi:10.5539/ass.v15n2p60
Accepted: December 13, $2018 \quad$ Online Published: January 30, 2019

URL: https://doi.org/10.5539/ass.v15n2p60

\begin{abstract}
Drumline has gained more popularity as an independent percussion group with its new music arrangement and attractive drum groove. It is seen that a quite number of drumline groups have been established in Malaysia as part of music activities such as secondary school and university drumline and community group. However, the insufficient emphasis or highlights has likely created diverse perceptions on the development of drumline groups as they have the tendency to have different reasons for joining a drumline group. Therefore, to further investigate this matter, the study focuses on four subscales of intrinsic motivation of Intrinsic Motivation Inventory (IMI), which are (a) Interest-enjoyment dimension, (b) Effort-importance dimension, (c) Value-usefulness dimension, and (d) Pressure-tension dimension. The data is collected using questionnaire, with the consideration of the members' demographic profile, motivation and factors that contribute to the success of drumline groups, specifically in Malaysia. Based on the findings, majority of the members perceived their interest-enjoyment as a reason to join in the drumline ensemble group. They have an agreement on the fact that drumline is a great activity to participate as it is enjoyable and exciting. Also, it is identified that teamwork, enjoyment, and dedication were among the factors that contribute to successful drumline groups. In general, the members are motivated, despite the lack of sponsorship for drumline event or competition.
\end{abstract}

Keywords: Drumline, intrinsic motivation, interest-enjoyment dimension, marching band \& community music

\section{Introduction}

Drumline has found a niche as one of the popular percussive arts in Malaysia. According to Summerlin (2016), drumline can be defined as a marching percussion section of a drum and bugle corps or marching band. Normally, the instrument in drumline ensemble comprised of high-tension snare drums, tenor drums, bass drums, and crash cymbals. The influence of drumline in Malaysia started during the era of colonization as marching band was part of the co-curriculum activity in majority of schools in urban areas. Subsequently, in 1995, the concept of American Contemporary Style of Marching Band was introduced, and since then, it is implemented as a new performance style. The style is quickly adapted and one of the most significant changes is the replacement of instrument in which side drum is substituted with a high-tension snare drum (Zain, 2013). Ultimately, the drumline community began to revolve and soon enough, divided into three types which are (a) Secondary school drumline group, (b) University drumline group, and (c) Community drumline group. Most of the secondary school and university drumline groups are part of school or university marching band ensemble, excluding community drumline groups because the group is known as an independent unit. For instance, Kuala Lumpur Drum Corps (KLDC) is the first community drumline group in Malaysia founded by YM Raja Zainal Badri and three other co-founders, which purposely to bring drumline performance and music to a new level with a variety of experimental music genres. Also, Batteryheadz Percussion (BHP) is one of the community drumline groups which is founded by Zahrein Mustaffa and Shamsulzaman Samsudin in 2010. Its establishment is to provide a platform for young people in Malaysia to enjoy and express their musical experience through drumline percussions (Battle, 2014). Commonly, these groups do provide weekly trainings even though the members do have comprehensive knowledge on the music theory, drumline rudiments, cadences and drumline music.

With the increasing number of drumline groups, event organizers started to organize various national and international competitions in Malaysia. For example, in 2008, Present Malaysia and World Association of 
Marching Show Band in conjunction with the Ministry of Tourism Malaysia had held an international competition, called Kuala Lumpur World Marching Show Band Competition 2008 (Ministry of Tourism, 2008). Other than that, several annual marching band events are organized for the drumline community such as Malaysia World Band Competition (MWBC) by ZI Production (Drum Corps Europe, 2010), School of X (SOX) Drum Battle by Celcom Axiata Berhad (Celcom, 2010) and Universiti Teknologi Mara (UiTM) Drum Competition by the university itself (Utusan Online, 2012). These types of events are considered appealing as the young generations are given the opportunity to get involved and as Buyer (2007) has discussed, drumline helps the members to have passion, especially in music. In other words, drumline is one of the popular music ensembles and the competitions have provided a platform in bringing drumline groups together to display one's talents and potentials. However, research on drumline community is unlikely to be found, specifically in Malaysia. Therefore, the study aims to identify the perception among members, focusing on motivation and factors that contribute to successful drumline groups in Malaysia. Based on the identified objectives, the research questions are:

1. What is the perception among members of drumline group in Malaysia according to the four subscales of intrinsic motivation of IMI (interest-enjoyment dimension, effort-importance dimension, value-usefulness dimension and pressure-tension dimension)?

2. What are the factors that contribute to successful drumline groups in Malaysia?

\subsection{Literature Review}

Motivation is essential in order to achieve success as it stimulates one's actions to accomplish goals. As Bandura and Cernova (2000) have discussed in a study, when goals are established, it is easier for an individual to be motivated as he or she is driven to achieve certain standards against which performance would be assessed. Also, Schmidt (2005) and Schatt (2011) acknowledged that motivation is a key element to be considered in playing musical instruments because it may not only reflect on one's determination to acquire musical skills, but also the participation, especially in music group or band. Yet, practitioners have different approaches and understanding on the concept of motivation because an individual has the tendency to have different perceptions on what motivates him or her. Therefore, there are various theories which could be explicated from the aspects of motivation such as one's drive, competency, achievement and reinforcement.

According to Ryan and Deci (2000), intrinsic motivation reflects innate propensity of learning and integrating. It focuses on the individual's satisfaction when completing a task instead on separable consequence such as external urges, pressure and rewards. In other words, it is not necessarily to have external reward or support in order to achieve success. For example, as indicated by Schatt (2011), intrinsic motivation is highly stimulated outside of the classroom or lessons because one is inspired to put effort voluntarily. Also, it is mentioned in the study that an individual is encouraged to practice and presumably to become a well-rounded musician when he or she is intrinsically motivated, especially through private lessons. Intrinsic motivation also focuses on the engagement in an activity as it is related to the elements of autonomy, competency and relatedness of an individual.

One of the subscales to be deliberated in intrinsic motivation is interest. As mentioned by Ryan and Deci (2000), an individual has higher tendency to be intrinsically motivated when the activity is interesting enough and suits his or her passion. For example, based on a study by Jacobs, Finken, Griffin and Wright (1998) on adolescent students, by measuring their rating on provided Biology assignments whether it is considered interesting or boring, it is discovered that their "current intrinsic interest" have a strong influence on the choice of career in the field of science. Likewise, Hidi and Berndoff (1998) have found that, even though a female student has no prior background in a certain field, the motivation to develop interest in psychology class is affected by her situational interest. Thus, Hruska (2011) has emphasized on the importance of intrinsic motivation because learning its own is rewarding and satisfying, specifically in music education. It is suggested that the teachers should encourage the students to be intrinsically motivated as it would provide a better platform for them to be authentic in exploring their interest.

Other than that, a study by Schmidt (2005) has shown that performance and effort ratings are respectively correlated to self-concept and intrinsic motivation. Similarly, Legette (1998) has established in a study related to success and failure in music that students of public schools are highly depending on their ability and effort as casual attributions of an achievement or otherwise, especially among the female students. It is further explained that successful students are more prone to achieve success in future when they believe that they have worked hard and shown much effort. For example, Buyer (2007) has mentioned that percussion players are likely to spend more time in practices to ensure they are able to play well. Accordingly, John (2006) stated that teachers 
could improve the learning experience by sharing values for student's efforts, providing good and meaningful feedbacks, and promoting collaborative music making.

Besides, self-esteem and motivation are interdependent when an individual contemplated on his or her capability of certain activity (Harter, 1998). It is added in the study, the ability to form congruent hierarchies of task values and competence beliefs should lead to higher self-esteem and continuing motivation, whereas incongruent hierarchies of beliefs will lead to negative self-esteem and lowered motivation. For example, an individual could accept being incompetent by lowering the value of an activity, whereas tend to enhance the activity's value when he or she alleged that he or she has high competency in certain skills. In fact, Coulson and Burke (2013) have identified that the students have higher tendency to produce creative and original music if they are more confident with their musical ability, especially when music is anticipated as an interesting activity. Moreover, a study by Schatt (2013) on public school students has shown that majority of them seemed to be fascinated in learning more about their instrument, completing a task successfully and experiencing the positive stimulation of music. In relation to the value hold by the students, Barret and Bond (2015) have discovered that musical competency does not only benefits an individual's confidence in playing musical instruments but including other areas such as self and social confidence. However, Wigfield and Eccless (1992) has indicated that there are students who doubted their utility value (usefulness) and attainment value (importance) of certain subjects in schools. It is due to the age of students find it challenging to attain success throughout the school years, especially in mathematical, reading, musical skills, and sports. Aside from self-belief, it is also believed that the value of a group is also depending on social support of one another (Criss, 2010). It is highlighted in the study on the importance of good relationship as it would strengthen the bonds and create strong teamwork among the students. When they supported each other, they are somehow valued and well appreciated as the others have recognized his or her contribution. Namely, meaningful relationship has helped the students to achieve success as an individual and also a group.

In addition to other subscales, pressure is an element to be examined in understanding intrinsic motivation. According to Sansone and Smith (2000), students would usually be negatively affected, rather than positively motivated when facing social pressure. As discussed in a study by Evans, McPherson and David (2013), students tend to feel pressured when they are labelled as a "geek" or not "cool" and hardly socialize with other members in the group. Relatedly, the students with particular responsibility also have higher probability to encounter challenges (Melton, 2012). For example, a leader may have to face problematic members who have discipline issues or lack of interest in being a part of the group. Yet, Criss (2010) informed that the peer pressure could play positive role as a motivational factor, especially when members care for each other in the group. In brief, an individual has different intrinsic motivation and based on multiple research, the students are different reasoning in achieving success.

Based on an article entitled "The drumline experience: How much is too much", Buyer (2006) stated that each member has his or her own reason in joining a drumline group. There are members who perform to succeed and continuously challenge themselves to accomplish perfection, while others considered drumline as a source of enjoyment since they have the opportunity to perform. Consequently, there are different factors which contributed to the success of a drumline group. According to Buyer (2009), it is determined that the five factors that have an influence on its excellence of 7 top university drumline groups in the United States are culture, staff and member leadership, rehearsal time, number of shows and competitive audience. For instance, the culture integrated in a drumline group is crucial as it would influence the members' ethics. In the University of North Texas, the band director emphasized on the importance of respecting each other, working hard and making right choices, despite the difficult situation.

It is highlighted in the article that leadership among the staff and member has helped to establish the sense of ownership and responsibility among them. Also, in the University of Alabama, "Role Model Leadership" (RML) is implied among the members of drumline group, focusing on the needs to portraying good manner to be a good role model. The staffs and members are expected to always be on time, work hard, exhibit passion, show commitment and respect. Indeed, it is further discussed during Percussion Art Society International Conference 2006 (PASIC) and Buyer (2007) has summarized that students who joined drumline groups have better exposure in life skills such as work ethics, persistency and responsible.

Despite the factors which contribute to the success of a drumline group, there are issues which require careful attention in order to sustain the achievements. According to Abril (2008), the fund allocated for music program is known to be one of the challenges encountered, specifically in schools. With a survey sent to 100 school principals in the United States, $54 \%$ of them have agreed upon the high cost of music program to be the main reason for insufficient participation among the students. It is informed that the schools could not afford to endure 
the expenses such as practice routines and instruments. Therefore, it is suggested for the music educators and administrators to only offer music program with lower cost instead of drumline percussion, such as general music, guitar, technology and composition classes.

Likewise, Shah and Saidon (2012) have identified that funding is one of main challenges in the development of music activities in Malaysia. It is simply demanding for the organizers to get sponsorship in order to organize national and international marching band or drumline competitions. Furthermore, it is discovered that most of the potential sponsors are willing to contribute in terms of non-monetary such as in-kind or volunteers, instead of monetary funding. In other words, the involvement of drumline groups in the country is rather limited due to insufficient fund and constrained sponsorship. Hence, it is suggested by the directors and managers whom participated in Malaysia National Band Competition in 2010 and/or 2011 to reconsider the prizes for winning groups. It is essential to make sure the prizes allocated are worth the time, cost and effort of the members because they are highly committed to participate and perform in the competitions. It is expected for the organizers or other responsible committees to show their appreciation on the performances through their prizes.

State why the problem deserves new research. For basic research, the statement about importance might involve the need to resolve any inconsistency in results of past work and/or extend the reach of a theoretical formulation. For applied research, this might involve the need to solve a social problem or treat a psychological disorder. When research is driven by the desire to resolve controversial issues, all sides in the debate should be represented in balanced measure in the introduction. Avoid animosity and ad hominem arguments in presenting the controversy. Conclude the statement of the problem in the introduction with a brief but formal statement of the purpose of the research that summarizes the material preceding it. For literature reviews as well as theoretical and methodological articles, also clearly state the reasons that the reported content is important and how the article fits into the cumulative understanding of the field.

\section{Method}

The respondents for the study were selected among the members of drumline groups in Malaysia. Based on purposive sampling, the gender, years of involvement and choice of drumline group (school, university or community drumline) among respondents were the criteria considered in order to acquire to the needs of study.

\subsection{Research Instrument}

The survey questionnaire consists of three sections which are Section A, B and C and a pilot study was conducted before distributing to the respondents. Based on the result, the Cronbach's alpha Section B was .823 and .803 for Section $\mathrm{C}$, which indicated that the items included were reliable for the purpose of the study. For Section A, items are developed to gather information on the demographic profile of the members such as gender, choice of drumline group and years of involvement. Meanwhile, for Section B, the items are adapted from a study by Ryan (1982) who first developed the Intrinsic Motivation Inventory (IMI), however, some changes are made to explicate required data, particularly among the member of drumline groups in Malaysia. It comprises of 20 items and each of the items is based on the four subscales which included (a) Interest-enjoyment dimension, (b) Effort-importance dimension (c) Pressure-tension dimension and (d) Value-usefulness dimension. While for Section C, the 14 items included are adapted from a study by Deisler (2011) related to characteristic of successful high school band program and Soundlink online questionnaires on community music success (Bartleet, Dunbar-Hall, Letts, \& Schippers, 2009) with the intention to emphasize on the respondents' perceptions on factors which contribute to the success of drumline groups. Throughout the survey questionnaire, the respondents are required to answer all items included and respond to a 7 -point Likert scale $(1=$ Strongly disagree to $7=$ Strongly agree) to indicate their level of agreement on the provided items.

\subsection{Data Collection}

The survey questionnaire was distributed via online, using the Qualtrics survey platform to ensure maximal variation of sampling. With the use of this survey platform, the respondents were given the flexibility of time and setting to respond to the items as it provided a mobile friendly survey. Besides, it allowed the researcher to save time and reach respondents from further away. Hence, the variation of respondents would increase the validity rate of the study

\section{Results}

The data below is divided into three sections which are demographic profile, motivations among members of drumline group and factors that contribute to successful drumline groups, specifically in Malaysia. 


\subsection{Demographic Profile}

There were 82 respondents involved in the study, with 63 (76.8\%) male and 19 female (23.2\%) members of drumline groups in Malaysia. It is further explained in the tables below according to the members' choice of drumline group and years of involvement.

Table 1. Cross tabulations of respondents based on choice of drumline group and years of involvement

\begin{tabular}{ccccc}
\hline \multirow{2}{*}{ Drumline group } & \multicolumn{4}{c}{ Years of involvement } \\
\cline { 2 - 5 } & Less than a year & $1-5$ years & $6-10$ years & More than 10 years \\
\hline School drumline group & 5 & 26 & 5 & 0 \\
University drumline group & 5 & 11 & 3 & 0 \\
Community drumline group & 3 & 11 & 11 & 2 \\
Total & 13 & 48 & 19 & 2 \\
\hline
\end{tabular}

Table 1 presents the members' choice of drumline group and years of their involvement. For those who joined school drumline group, 5 had less than a year, 26 had 1 to 5 years and another 5 had 6 to 10 years of involvement. While for members who enrolled in university drumline group, 5 had less than a year, 11 had 1 to 5 years and only 3 had 6 to 10 years of involvement. Finally, for the members from community drumline group, 3 has less than a year, 11 had 1 to 5 years and 6 to 10 years, respectively and another 2 had more than 10 years of involvement. In general, it can be concluded that majority of the members from all drumline groups had 1 to 5 years of involvement, followed by 6 to 10 years and less than a year of involvement. Whereas, the least and only members who joined community drumline group had more than 10 years of involvement.

\subsection{Perception among the Members of Drumline Groups in Malaysia}

The data focuses on the four subscales of intrinsic motivation of IMI: interest-enjoyment, effort-importance, value-usefulness, and pressure-tension. It consisted of five items for interest-enjoyment, three items for effort-importance, eight items for value-usefulness and four times for peer-pressure dimension.

Table 2. Descriptive statistics for intrinsic motivation based on interest-enjoyment dimension

\begin{tabular}{ccc}
\hline Items & $M$ & $S D$ \\
\hline Drumline is a great activity to participate & 6.51 & .671 \\
I think drumline is enjoyable & 6.49 & .984 \\
I would describe drumline as very exciting & 6.46 & .688 \\
I am interested to join drumline & 6.32 & 1.005 \\
I will suggest my friends to join drumline & 6.10 & .989 \\
\hline
\end{tabular}

Table 2 displays that the highest score for intrinsic motivation based on interest-enjoyment dimension is from the item "Drumline is great activity to participate" $(\mathrm{M}=6.51, \mathrm{SD}=.671)$, followed by "I think drumline is enjoyable" $(\mathrm{M}=6.49 \mathrm{SD}=.984)$, "I would describe drumline as very exciting" $(\mathrm{M}=6.46, \mathrm{SD}=.688)$, "I am interested to join drumline" $(\mathrm{M}=6.32, \mathrm{SD}=1.005)$ and finally "I will suggest my friends to join drumline" $(\mathrm{M}=6.10, \mathrm{SD}=.989)$. Hence, it is acknowledged that the members are interested in participating in drumline activity, yet they are least concern of suggesting their friends to join drumline group

Table 3. Descriptive statistics for intrinsic motivation based on effort-importance dimension

\begin{tabular}{ccc}
\hline Items & $M$ & $S D$ \\
\hline I put a lot of effort to participate in drumline & 6.34 & .757 \\
It is important for me to do well in drumline & 6.15 & .918 \\
I work hard to be in drumline & 5.98 & 1.077 \\
\hline
\end{tabular}

Based on Table 3, the item with highest mean score for intrinsic motivation based on effort-importance dimension is "I put a lot of effort to participate in drumline" $(\mathrm{M}=6.34, \mathrm{SD}=.757)$, followed by "It is important for me to do well in drumline" $(\mathrm{M}=6.15, \mathrm{SD}=.918)$ and "I work hard to be in drumline" $(\mathrm{M}=5.98, \mathrm{SD}=1.077)$. In general, it is determined that the members have mainly displayed much enough effort and participation in their drumline groups. 
Table 4. Descriptive statistics for intrinsic motivation based on value-usefulness dimension

\begin{tabular}{ccc}
\hline Items & $M$ & $S D$ \\
\hline Drumline could help me to work in a team & 6.44 & .904 \\
Drumline is useful to improve my musical skills & 6.39 & .978 \\
Joining drumline could help me to build self-confidence & 6.29 & .882 \\
I believe drumline could give more values to me & 6.29 & .824 \\
Drumline could help me to improve my artistic abilities & 6.06 & .934 \\
I can express myself when joining drumline & 5.96 & .853 \\
I will join drumline again because it holds personal value to me & 5.85 & 1.278 \\
Drumline is important for my creativity development & 5.80 & 1.127 \\
\hline
\end{tabular}

Table 4 indicates that the item "Drumline could help me to work in a team" $(\mathrm{M}=6.44, \mathrm{SD}=.904)$ has the highest mean score for intrinsic motivation based on value-usefulness dimension, followed by "Drumline is useful to improve my musical skills" $(\mathrm{M}=6.39, \mathrm{SD}=.978)$, "Joining drumline could help to build self-confidence" $(\mathrm{M}=62.9, \mathrm{SD}=.882)$, "I believe drumline could give more values to me" $(\mathrm{M}=6.29, \mathrm{SD}=.824)$, "Drumline could help me to improve my artistic abilities" $(\mathrm{M}=6.06, \mathrm{SD}=.934)$, "I can express myself when joining drumline" $(\mathrm{M}=5.96, \mathrm{SD}=.853)$, "I will join drumline again because it holds personal value to me" $(\mathrm{M}=5.85, \mathrm{SD}=1.278)$ and "Drumline is important for my creativity development" $(\mathrm{M}=5.80, \mathrm{SD}=1.127)$. Based on the findings, it is simplified that drumline has a positive impact on majority of the members.

Table 5. Descriptive statistics for intrinsic motivation based on pressure-tension dimension

\begin{tabular}{ccc}
\hline Items & $M$ & $S D$ \\
\hline I feel relaxed when participate in drumline & 5.63 & 1.139 \\
I do not feel nervous when participate in drumline & 4.45 & 1.604 \\
I feel tensed when participate in drumline & 4.21 & 1.748 \\
I feel pressured when participate in drumline & 4.10 & 1.667 \\
\hline
\end{tabular}

According to Table 5, the highest mean score for intrinsic motivation based on pressure-tension dimension is from item "I feel relaxed when participate in drumline" $(\mathrm{M}=5.63, \mathrm{SD}=1.139)$, "I do not feel nervous when participate in drumline" $(\mathrm{M}=4.45, \mathrm{SD}=1.604)$, "I feel tensed when participate in drumline" $(\mathrm{M}=4.21, \mathrm{SD}=1.748)$ and "I feel pressured when participate in drumline" $(\mathrm{M}=4.10, \mathrm{SD}=1.667)$. Thus, it is identified that the members are calm and less anxious when they participate in a drumline group.

Table 6. Descriptive statistics for overall intrinsic motivation

\begin{tabular}{ccc}
\hline Subscales & $M$ & $S D$ \\
\hline Interest-enjoyment dimension & 6.37 & .867 \\
Effort-importance dimension & 6.16 & .917 \\
Value-usefulness dimension & 6.14 & .972 \\
Pressure-tension dimension & 4.60 & 1.54 \\
\hline
\end{tabular}

Referring to Table 6 above, it shows that the highest mean score for intrinsic motivation is Interest-enjoyment dimension $(\mathrm{M}=6.37, \mathrm{SD}=.867)$, followed by Effort-importance dimension $(\mathrm{M}=6.16, \mathrm{SD}=.917)$, and Value-usefulness dimension $(\mathrm{M}=6.14, \mathrm{SD}=.972)$, whereas the lowest score is attained by Pressure-tension dimension $(\mathrm{M}=4.60$, SD1.54). Largely, it is shown that the members are intrinsically motivated based on Interest-enjoyment dimension, compared to Effort-importance, Value-usefulness and Pressure-tension dimensions.

\subsection{Factors that Contribute to Successful Drumline Groups}

The table below signifies the factors that contribute to successful drumline groups according to the members of drumline groups in Malaysia.

Based on Table 7, the highest score is obtained from "Drumline member's teamwork" $(\mathrm{M}=6.50, \mathrm{SD}=.864)$, followed by "Member's enjoyment in drumline group" $(\mathrm{M}=6.48, \mathrm{SD}=.671)$, "Member's dedication to drumline group" $(\mathrm{M}=6.32, \mathrm{SD}=.901)$, "High quality drumline show" $(\mathrm{M}=6.22, \mathrm{SD}=.875)$ and "Drumline member's motivation" $(\mathrm{M}=6.20, \mathrm{SD}=.987)$. While the lowest score is from the item "Drumline member's private lessons" 
$(M=5.45, S D=1.219)$, followed by "High quality instrument" $(M=5.72, S D=1.010)$, "Drumline instructor's high expectation" ( $\mathrm{M}=5.74, \mathrm{SD}=1.205)$, "Parent's support" $(\mathrm{M}=5.77, \mathrm{SD}=1.250)$ and "Effective public relationship $(\mathrm{M}=5.77, \mathrm{SD}=1.046)$. Thus, it determines that majority of the members have highly agreed on the importance of teamwork, interest and dedication, quality of a show and their motivation are the factors contributing to the success of the drumline groups. However, the members have denoted that private lesson, quality of instrument, high expectation and support of parents to be the least important factors that contribute to successful drumline groups.

Table 7. Descriptive statistics of highest means for factors that contribute to successful drumline groups

\begin{tabular}{lcc}
\hline Items & $M$ & $S D$ \\
\hline Drumline member's teamwork & 6.50 & .864 \\
Member's enjoyment in drumline group & 6.48 & .671 \\
Member's dedication to drumline group & 6.32 & .901 \\
High quality drumline show & 6.22 & .875 \\
Drumline member's motivation & 6.20 & .987 \\
Hard working drumline staff & 6.18 & .833 \\
Careful planning with a forward planning of activities & 6.16 & .777 \\
Drumline instructor's personality & 6.15 & .918 \\
Supportive administration/principal & 6.12 & 1.035 \\
A well organizational structure & 6.12 & .837 \\
Highly skilled drumline instructors & 6.11 & .994 \\
A good choice of repertoire/style/genre & 6.11 & .930 \\
Quality rehearsal space & 6.11 & .903 \\
Mentoring leadership among the members & 6.02 & 1.018 \\
Attention to sustainability in the drumline community & 6.02 & .801 \\
Challenging drumline music & 5.98 & .942 \\
A tradition to gain success & 5.93 & 1.075 \\
Sufficient funding & 5.83 & 1.284 \\
A good location, venue and facilities & 5.83 & .979 \\
Networking with local organizations & 5.82 & .877 \\
Effective public relationship (PR) & 5.77 & 1.046 \\
Parent's support & 5.77 & 1.250 \\
Drumline instructor's high expectation & 5.74 & 1.205 \\
High quality instrument & 5.72 & 1.010 \\
Drumline member's private lessons & 5.45 \\
\hline
\end{tabular}

\section{Discussion}

The research questions are answered with regards to the tabulated findings and previous literature review, particularly on intrinsic motivation among the members and factors to successful drumline group in Malaysia.

4.1 Research Question 1: What is the perception among members of drumline group in Malaysia according to the four subscales of intrinsic motivation of IMI (interest-enjoyment dimension, effort-importance dimension, value-usefulness dimension and pressure-tension dimension)?

Referring to the findings on intrinsic motivation, most of the respondents of different drumline groups have indicated that they are highly motivated by interest-enjoyment dimension, followed by effort-importance, value-usefulness and pressure-tension dimension.

For interest-enjoyment dimension, majority of the members agreed that drumline is a great activity to join, considering it as enjoyable and exciting. Yet, the members have the least concern to suggest their friends to join drumline group because they tend to only focus on developing their own interest or passion. Similarly, as supported by Ryan and Deci (2000), one is intrinsically motivated when the activity is considered to be interesting enough for him or her. Hruska (2011) has also mentioned that learning itself can be rewarding and satisfying for individuals who are provided with better access to explore their interest. Largely, it is shown in the 
findings that the members are voluntarily participating in the activities of drumline groups for their self-assurance and doubtfully for other external reasons.

Based on the effort-importance dimension, the members of drumline group indicated that they have put a lot of effort in the music practices. Besides, they recognized the importance of doing well in drumline and most of them agreed that they have worked hard to continue being in the drumline group. Likewise, Legette (1998) has informed in a study that an individual is most likely to rely on his or her ability and effort as the key to success or failure. For example, Buyer (2007) stated in a study that percussion players did spend more time during practices to ensure they would be able to play well. Therefore, these members are aware of the fact that they have to make an effort in order to stay relevant, especially among the other members of their drumline group.

Referring to value-usefulness dimension, the members are convinced that joining drumline group has positive effects on their skills and abilities. In the findings, most of the members believed that drumline could help them to work in a team, improve musical skill and build up their self-confidence. They also agreed that drumline has given them more values and improve their artistic abilities as they are able to express themselves. As a matter of fact, the members will join drumline again due to its personal value and it is important for their creativity development. Similarly, Buyer (2007) has discovered that individuals who joined drumline could have better opportunity to learn great life skills, such as ethic, teamwork, persistence, and responsibility. It is further discussed by Barrett and Bond (2015) who mentioned that music competency could not only improve one's ability to play an instrument but also his or her self-confidence. Fundamentally, the members do hold a certain value upon their participation in drumline group as it has helped to improve and enhance their skills and abilities.

For pressure-tension dimension, it is identified that majority of the members are relaxed and do not feel nervous when participating in drumline. In other words, they are calm and have less anxiety to be part of the drumline group. In contrast to a study conducted by Sansone and Smith (2000), individuals would typically be affected when experience social pressure. For example, Evans, McPherson and David (2013) have informed that students tend to have difficulty to socialize when they are considered as the minority of the group. Thus, it can be concluded that the members have unlikely encountered any much pressure from the group as they are mostly in peace.

\subsection{Research Question 2: What are the factors that contribute to successful drumline groups in Malaysia?}

According to the findings, the members agreed that teamwork, personal interest and dedication, quality of a show and their motivation are the most important factors to achieve success in a drumline group. Relatable to a study by Buyer (2009), the culture integrated in a drumline group would very much contribute to the members' ethics. Also, Schmidt (2005) and Schatt (2011) have further discussed that an individual's motivation to play musical instruments may not only reflect on his or her determination to acquire certain skills, but also the urge to participate in an activity in a group or band. Therefore, it can be generalized that there is a combination of different factors that contribute to successful drumline group in Malaysia, depending on the culture or norms instilled among themselves.

Firstly, majority of the members believed that teamwork highly contributes to the success of a drumline group. As Criss (2010) has emphasized on establishing good relationship, an individual should learn to work with one another in order to strengthen their bonds and create better teamwork. They have to continuously encourage and recognize each other's contribution to ensure everyone is valued and appreciated in the group. However, it is presented in the findings that support from parents has the least importance towards better achievement in a drumline group. The members do not acknowledge the significance of their parents support in order to achieve or attain the success of their drumline group. Conclusively, teamwork or being supportive is essential merely among the members as the essence of a drumline group is to harmonize and complement each other based on the music arrangement.

Besides, the enjoyment and dedication among members are recognized to have an influence on successful drumline group, excluding the instructor's high expectation. It is seen that the members are only focusing on themselves and have the slightest consideration on the instructor's high expectation. Correspondingly, Buyer (2006) has mentioned that the members would join a drumline group due to their interest or passion in performing. It is also stated by Ryan and Deci (2000), one would develop an interest when the activity suits his or her passion. Therefore, it is essential for the members to have the urge to learn or participate in musical activities, despite external rewards or support in achieving success for themselves and also the group.

Moreover, the quality of a show is another factor that reflect on the success of a drumline group. For example, Buyer (2006) has summarized that number of shows and competitive audience are the elements to be measured in enhancing the quality. Whereas, as suggested by Shah and Saidon (2012), the prizes allocated for a music 
competition should be reconsidered to appreciate the time, cost and effort of the participants. Yet, it is shown in the findings that effective public relationship (PR) and high-quality instruments are unconvincingly to improve the quality of a show. Hence, it can be assumed that drumline groups have different concerns or issues when identifying the elements to increase the quality of a show.

Finally, motivation among the members is acknowledged as one of the factors towards successful drumline group. Likewise, Bandura and Cernova (1983) have mentioned that motivated individuals are driven to achieve certain standards in which their performance would be assessed. The members are willing to make an effort to make sure they are able to become well-rounded musicians, but in contrast to Schatt (2011), they do not rely on private lessons to improve their musical skills. Thus, it is simplified that the members are self-motivated, and they do not depend on other external rewards or support when thriving for success in a drumline group.

\section{Conclusion}

In general, the study has highlighted the perception of members on their motivation and factors that contribute to successful drumline groups. While an individual has different perceptions on the concept of motivation, the members of drumline groups in Malaysia are intrinsically motivated to be part of an ensemble, especially by interest-enjoyment dimension. They seem to be mindful of personal interest and passion in learning and developing their musical skills. Besides, in relation to the factors that would contribute to the success of drumline groups, the members have again agreed upon the importance of their enjoyment, dedication and motivation. Also, the teamwork among members and quality of a show are identified to have an impact on successful drumline groups. Essentially, despite the different perceptions, the members of drumline groups in Malaysia are more concerned of their self-satisfactory in achieving success for not only themselves, but also the group as a whole.

\section{References}

Abril, C. R., \& Gault, B. M. (2008). The State of Music in Secondary Schools: The Principal's Perspective. Journal of Research in Music Education, 56(1), 68-81. https://doi.org/10.1177/0022429408317516

Bailey, W. (2003). The Complete Marching Band Resource Manual: Techniques and Materials for Teaching, Drill Design, and Music Arranging. Pennsylvania: University of Pennsylvania Press.

Bandura, A., \& Cervone, D. (1983). Self-evaluative and self-efficacy mechanisms governing the motivational effects of goal systems. Journal of Personality and Social Psychology, 45(5), 1017-1028. https://doi.org/10.1037/0022-3514.45.5.1017

Barrett, M. S., \& Bond, N. (2015). Connecting through music: The contribution of a music programme to fostering positive youth development. Research Studies in Music Education, 37(1), 37-54. https://doi.org/10.1177/1321103X14560320

Bartleet, B., Dunbar-Hall, P., Letts, R., \& Schippers, H. (2009). Sound links: Community music in Australia. Nathan: Griffith University.

Buyer, P. (2006, October). The Drumline Experience: How Much is Too Much? Percussive notes. Retrieved from http://www.paulbuyer.com/article//Dline\%20Exp\%201.pdf

Buyer, P. (2007, April). The Drumline Experience II: Wisdom From the 12th Century. Percussive notes. Retrieved from http://www.paulbuyer.com/article//Dline\%20Exp\%202.pdf

Buyer, P. (2009, June). Secrets of Success from Top College Drumlines. Percussive notes. Retrieved from http://www.pas.org/Files/0906.18-19.pdf

Celcom (2010). S.O.X. All-Stars Drum and Dance: Malaysia's First and Largest Inter-School Challenge In Drumline And Cheer Dance! Retrieved from https://www.celcom.com.my/Web_Center_Sites/PBO/Files_ Corporate/Media_Release/2010/mar-2010-20.pdf

Coulson, A. N., \& Burke, B. M. (2013). Creativity in the elementary music classroom: A study of students' perceptions. Int. J. of Music Education, 31(4), 428-441. https://doi.org/10.1177/0255761413495760

Criss, E. (2010). Teamwork in the Music Room. Music Educators Journal, 97(1), 30-36. https://doi.org/10.1177/0027432110380550

Deisler, A. M. (2011). A Comparison of Common Characteristics of Successful High School Band Programs in Low Socioeconomic Status Schools and High Socioeconomic Status Schools. (Electronic Thesis or Dissertation). Retrieved from https://fsu.digital.flvc.org/islandora/object/fsu:168951/datastream/PDF/view

Drum Corps Europe. (2010). Drum corps is growing in Malaysia. Retrieved from 
https://drumcorpseurope.org/newsitem.php?id=7920

Drumline Battle. (2014). Batteryheadz Percussion, Ampang Malaysia. Retrieved from http://www.drumlinebattle.com/albums/batteryheadz-percussion-ampang-malaysia/

Evans, P., McPherson, G. E., \& Davidson, J. W. (2013). The role of psychological needs in ceasing music and music learning activities. Psychology of Music, 41(5), 600-619. https://doi.org/10.1177/0305735612441736

Harter, S. (1998). The development of self-representations. In W. Damon, \& N. Eisenberg (Eds.), Handbook of child psychology: Social, emotional, and personality development (pp. 553-617). John Wiley \& Sons Inc.

Hess, J. (2010). The Sankofa Drum and Dance Ensemble: Motivations for student participation in a school world music ensemble. Research Studies in Music Edu., 32(1), 23-42. https://doi.org/10.1177/1321103X10370093

Hruska, B. J. (2011). Using Mastery Goals in Music to Increase Student Motivation. Update: Applications of Research in Music Education, 30(1), 3-9. https://doi.org/10.1177/8755123311418477

John, P. A. (2006). Finding and making meaning: Young children as musical collaborators. Psychology of Music, 34(2), 238-261. https://doi.org/10.1177/0305735606061854

KLDrumlineCorps Description. (2008). Retrieved from https://www.youtube.com/user/KLDrumlineCorps/about

Legette, M. R. (1998), Causal Beliefs of Public-School Students about Success and Failure in Music. Journal of Research in Music Education Spring, 46, 102-111. https://doi.org/10.2307/3345763

Melton, C. J. (2012). Facing the Music: Student Power Relations in Student Leadership within High School Band Programs (E-Thesis). Retrieved from https://digitalscholarship.unlv.edu/thesesdissertations/1757/

Ministry of Tourism, Malaysia. (2008). The KL World Marching Band Competition 2008. Retrieved from https://www.tourism.gov.my/media/view/the-kl-world-marching-band-competition-2008

Ryan, R. M., \& Deci, E. L. (2000). Self-determination theory and the facilitation of intrinsic motivation, social development, and well-being. The American Psychologist, 55(1), 68-78.

Sansone, C., \& Smith, J. (2000). Interest and self-regulation: The relation between having to and wanting to. In C. Sansone, \& J. M. Harackiewicz (Eds.), Intrinsic and Extrinsic Motivation: The Search for Optimal Motivation and Performance (pp. 341-372). San Diego, CA: Academic Press.

Schatt, M. D. (2011). High School Instrumental Music Students' Attitudes and Beliefs Regarding Practice: An Application of Attribution Theory. Applications of Research in Music Education, 29, 55-68. https://doi.org/10.1177/8755123310396981

Schatt, M. (2013). Middle School Band Students' Motivation to Practice: An Examination of Factors That Influence Self-Determination (Electronic Thesis or Dissertation). Retrieved from https://etd.ohiolink.edu/

Schmidt, C. P. (2005). Relations among Motivation, Performance Achievement, and Music Experience Variables in Secondary Instrumental Music Students. Journal of Research in Music Education, 53(2), 134-147. https://doi.org/10.1177/002242940505300204

Shah, S., \& Saidon, Z. (2012). Developing Malaysian High School Marching Bands Issues, Challenges and Strategies. Essays on Issues in Music and its Function: UM Book Series on Research in Musicology 4 (pp. 39-59). LAP Lambert Academic Publishing.

Summerlin, L. (2016). The History and Development of the Front Ensemble in Drum Corps International. (Electronic Thesis or Dissertation). Retrieved from https://etd.ohiolink.edu/

Syed Zain, S. (2013). Implementing Colour and dance in Marching Music. A Case Study on The Colourguard at The Victoria Institution cadet Corps Band (Unpublished Bachelor's Degree Thesis). University of Malaya.

Utusan Online. (2012). UiTM Pahang, Terengganu juara pertandingan Percussion. Retrieved from http://ww1. utusan.com.my/utusan/Pahang/20120523/wp_05/UiTM-Pahang-Terengganu-juara-pertandingan-Percussion

Wigfield, A., \& Eccles, J. S. (1992). The development of achievement task values: A theoretical analysis. Developmental Review. https://doi.org/10.1016/0273-2297(92)90011-P

\section{Copyrights}

Copyright for this article is retained by the author(s), with first publication rights granted to the journal.

This is an open-access article distributed under the terms and conditions of the Creative Commons Attribution license (http://creativecommons.org/licenses/by/4.0/). 